\title{
Lysine metabolism across the hindquarters of sheep; effect of intake on transfers from plasma and red blood cells
}

\author{
Isabelle C. Savary ${ }^{1}$, Simone O. Hoskin ${ }^{2}$, Ngaire Dennison ${ }^{2}$ and Gerald E. Lobley ${ }^{2}$ \\ ${ }^{1}$ INRA-Theix, 63122 St Genès Champanelle, France \\ ${ }^{2}$ Rowett Research Institute, Bucksburn, Aberdeen AB21 9SB, Scotland, UK
}

(Received 8 March 2000 - Revised 21 August 2000 - Accepted 13 November 2000)

\begin{abstract}
Both plasma and red blood cells contain amino acids (AA), but the relative amount of AA transferred from each vascular compartment to the tissues remains unclear. For splanchnic tissues, the relative transfers between the plasma, the red blood cells and the tissues may vary with nutritional state, but whether the same situation pertains for other tissues is not known. The current study focused on the transfer of lysine from plasma and red blood cells across the hindquarters of sheep offered four levels of intakes $(0.5,1 \cdot 0,1.5$ and $2.5 \times$ maintenance energy). This design, coupled with use of $\left[\mathrm{U}_{-}{ }^{13} \mathrm{C}\right]$ lysine as tracer, also allowed the effect of intake on protein kinetics to be examined. At all intakes, the concentration of lysine in the sheep' red blood cells exceeded that in plasma by $50 \%(P<0 \cdot 001)$, while the distribution of labelled lysine between the plasma and the red blood cells was 0.71:0.29. Net lysine uptake by the hindquarters increased in a linear manner $(P<0.001)$ with intake, with more than $90 \%$ extracted from the plasma. Free lysine enrichments in plasma from the posterior vena cava were less than that from the artery $(P<0 \cdot 001)$, but those in red blood cells were not different between the artery and vein. The red blood cells thus play a minor role in the transfers to and from the hindquarter tissues, regardless of intake. Based on plasma transfers and the enrichment of lysine in arterial plasma, hindquarter protein synthesis increased linearly with intake $(P<0 \cdot 001)$. In contrast, protein breakdown was unaffected by intake. The contribution of hindquarter protein synthesis to whole-body lysine flux remained unchanged with intake (18-20\%).
\end{abstract}

Lysine: Sheep: Hindquarters: Red blood cells: Plasma: Protein synthesis

Both plasma and red blood cells contain amino acids (AA). Thus either, or both, may be involved in transport between, and supply to, tissues. In many studies, however, only plasma exchanges are monitored. Early work (e.g. Pitts et al. 1963) suggested that tissue uptake of AA from blood and plasma were of similar magnitude, i.e. plasma transfers were dominant. Furthermore, analytical measurement of AA is less complex from plasma than blood, offering a technical convenience. Nonetheless, the relative contribution of red blood cells in vascular transport and tissue exchanges continues to be questioned for both ruminants and non-ruminants (e.g. Aoki et al. 1976; Hanigan et al. 1991; Le Floc'h et al. 1999).

For non-ruminants, AA concentration gradients between plasma and red blood cells are sensitive to nutrition. For example, in pigs, Keith et al. (1977) showed increases in lysine (and other AA) concentrations in both systemic plasma and the red blood cells after consumption of a semipurified diet containing casein. Furthermore, exchanges of AA between red blood cells and human splanchnic and forearm tissues were reported to be sensitive to the protein source in the diet (Aoki et al. 1976), although recent porcine data question such intake-linked differences (Le Floc'h et al. 1999).

The majority of studies reported for ruminants have focused on splanchnic transfers and with contradictory findings on the role of the red blood cells in net AA transfers (c.f. Heitmann \& Bergman, 1980; Houlier et al. 1991, v. Lobley et al. 1996). Furthermore, only a limited number of intakes have been compared. The present study, therefore, has examined the question of AA transfers from either plasma or red blood cells across the ovine hindquarters across an extended range of intakes $(0 \cdot 5,1$, 1.5 and $2.5 \times$ maintenance energy $(\mathrm{M}))$. The relationships

\footnotetext{
Abbreviations: AA, amino acid; ILR, irreversible loss rate; M, maintenance energy; mpe, molar percent excess; pAH, para-aminohippuric acid; PCV, packed cell volume.
}

* Corresponding author: Dr Isabelle C. Savary, fax + 334736246 39, email savary@clermont.inra.fr 
between peripheral tissue net AA retention and the differential changes in protein synthesis and degradation (Lobley, 1998) were also tested through infusion of a mixture of $\mathrm{U}_{-}{ }^{13} \mathrm{C}$-labelled AA. From these AA, lysine was selected for more detailed analysis because: (1) a concentration gradient exists between the red blood cells and plasma in most species (e.g. Keith et al. 1977; Hanigan et al. 1991); (2) the partition of lysine between plasma and the red blood cells has been reported to vary with the nature of the diet in non-ruminants (Keith et al. 1977). Part of these findings has been reported in preliminary form (Savary et al. 1999).

\section{Materials and methods}

\section{Experimental design}

Six Suffolk cross wether lambs (age 6-8 months, $30-35 \mathrm{~kg}$ live weight) were surgically prepared under halothanenitrous oxide anaesthesia and involved left flank incision, with retro-peritoneal exposure, to allow either polyvinyl or silicone rubber catheters to be inserted directly into the aorta (two) and posterior vena cava. The catheters were placed in the direction of blood flow with their tips caudal to the renal vessels. The tips of the two aortal catheters were placed approximately $3 \mathrm{~cm}$ apart, with the more cranial tip used for blood sampling and the caudal one for infusion of the blood flow marker, para-aminohippurate $(\mathrm{pAH})$. A temporary polyvinyl catheter was inserted into the jugular vein for infusion of labelled algal hydrolysate. On occasions, an aortal catheter lost patency and this was replaced by a temporary catheter into an auricular artery. Where recourse to the latter failed, a mixed sample of systemic blood was obtained via a catheter inserted into the right ventricle (this was necessary for six of the twenty-four infusions). Where failure of either of the aortal catheters occurred, analysis post mortem revealed this was usually due to entry of the tip into a side vessel. This was a postsurgery event as during the operation care was taken to ensure all of the catheter was within the aorta. In two cases, one of the catheters was embedded within the tissue of the aortal wall.

Animals were offered grass pellets $(10 \mathrm{MJ}$ estimated metabolizable energy $/ \mathrm{kg}$ DM; $26 \mathrm{~g} \mathrm{~N} / \mathrm{kg} \mathrm{DM}$ ) supplied daily as twenty-four equal portions each hour using automated feeders. Sheep were offered each of four levels of feed intake (corresponding to approximately $0.5,1.0,1.5$ and $2.5 \times \mathrm{M}$, based on daily $\mathrm{M}$ requirements of $400 \mathrm{~kJ} / \mathrm{kg}$ body weight ${ }^{0.75}$ ) in a Latin Square order, with two animal sequences repeated. The Latin Square design involved pairing of the lower two intakes $(0.5$ and $1.0 \times \mathrm{M})$ and the higher two $(1.5$ and $2.5 \times \mathrm{M})$, with the order randomised within and between pairs. This option was selected to minimise any compensatory growth effects, or dietary upsets, consequent to moving between dietary extremes during adjacent measurement periods. Each level of intake was fed for 2 weeks, except for the $0.5 \times \mathrm{M}$ ration that was fed for 1 week, but was preceded with $7 \mathrm{~d}$ at $\mathrm{M}$ intake. Measurements of amino acid kinetics were made on the last day of each period and involved infusion of $\mathrm{U}^{13}{ }^{13} \mathrm{C}$-labelled hydrolysate.
The preparation of the ${ }^{13} \mathrm{C}$-labelled amino acids from Celtone-C (Martek Biosciences Corporation, Columbia, MD, USA) was as previously described for algal biomass (Lobley et al. 1996). The dried hydrolysate was diluted in $0.05 \mathrm{M}$-sodium phosphate buffer, $0.10 \mathrm{M}-\mathrm{NaCl}(100 \mathrm{ml} /$ $1.0 \mathrm{~g}$ original Celtone-C powder (Martek Biosciences Corporation)), filtered under aseptic conditions and $100 \mathrm{ml}$ portions freeze-dried. Immediately prior to use, this powder was re-suspended in $400 \mathrm{ml}$ sterile water and re-filtered $(0.2 \mu \mathrm{m}$ filter $)$ under aseptic conditions. The AA composition of the hydrolysate was determined by ionexchange chromatography (Alpha Plus Amino Acid Analyser; Pharmacia-LKB Biochrom Ltd, Cambridge), with L-norleucine as external standard. The Celtone-C powder (Martek Biosciences Corporation) contained $300 \mu \mathrm{mol} \mathrm{L}-1 y s i n e / g$ at an enrichment of 99 molar percent excess (mpe). The concentration of each infusate was determined individually.

\section{Infusion protocols and blood sampling}

The hydrolysate was continuously infused (40 g infusate/h) into the jugular vein over a $10 \mathrm{~h}$ period. Between hours 3 to 9 , a solution of $0.15 \mathrm{M}$-sodium $\mathrm{pAH}(\mathrm{pH} 7.4 ; 20 \mathrm{~g} / \mathrm{h})$ that contained sodium heparin $(400 \mathrm{IU} / \mathrm{g})$ was infused into the downstream aortal catheter to allow the determination of blood flow. Integrated blood samples were withdrawn continuously by peristaltic pump from the other aortal catheter (or that placed in an auricular artery or the heart) and the vena cava $(10 \mathrm{ml} / \mathrm{h}$ per catheter) over hourly intervals during the last $4 \mathrm{~h} \mathrm{pAH}$ infusion (Lobley et al. 1995). Packed cell volume (PCV) was determined by haematocrit. After $9 \mathrm{~h}$, the infusion of heparinised pAH was discontinued, but the infusion of ${ }^{13} \mathrm{C}$-labelled AA was maintained, and $1 \mathrm{~h}$ later a small biopsy (about 200-400 mg) was taken under local anaesthesia from the skin of one leg and the underlying $m$. vastus lateralis. These tissue samples were carefully washed free of any superficial blood contamination in ice-cold $0 \cdot 15$ $\mathrm{M}-\mathrm{NaCl}$ and rapidly frozen in liquid $\mathrm{N}$, subsequent to storage at $-80^{\circ} \mathrm{C}$. Biopsies were taken from alternate legs for subsequent infusions.

Approximately $7 \mathrm{ml}$ blood was centrifuged at $1000 \mathrm{~g}$ for $10 \mathrm{~min}$ and $1 \mathrm{~g}$ plasma taken for $\mathrm{pAH}$ analysis. A further $1 \mathrm{~g}$ plasma was stored in a microcentrifuge tube at $-20^{\circ} \mathrm{C}$ for later enrichment analysis. To another $1 \mathrm{~g}$ plasma was added $0.3 \mathrm{~g}$ diluted solution of the hydrolysate infusate for measurement of AA concentration by the isotope-dilution technique (Calder et al. 1999). The blood samples were processed in a similar way to plasma samples, but involved addition of an equal volume of ice-cold pure water to induce haemolysis of the samples. Samples of blood and plasma were obtained on the day prior to infusion to provide background (natural abundance) samples for GCMS analyses. Tissue samples (200 mg) were homogenised at $4^{\circ} \mathrm{C}$ in $3 \mathrm{ml}$ water, deproteinised with 0.15 volumes sulfosalicyclic acid (480 g/l) and treated as for blood and plasma samples for determination of isotopic enrichment.

\section{Chemical analyses}

Plasma flow $(\mathrm{kg} / \mathrm{min})$ was determined gravimetrically as 
described previously (Lobley et al. 1995). Blood flow was then derived from: plasma flow/(1-PCV). Samples of the stored plasma and haemolysed blood were thawed to $4^{\circ} \mathrm{C}$ (necessary to limit peptide hydrolysis within the sample), deproteinized by addition of $0 \cdot 15$ volumes sulfosalicylic acid $(480 \mathrm{~g} / \mathrm{l})$ and centrifuged at $13000 \mathrm{~g}$ for $15 \mathrm{~min}$. The supernatant fractions were then desalted by application to 0.6 ml Dowex-50 $\left(\mathrm{H}^{+}, 100-200 \mathrm{mesh}, \times 8\right)$, washed twice with $1 \mathrm{ml}$ water and eluted with $3 \mathrm{ml} 4 \mathrm{M}-\mathrm{NH}_{4} \mathrm{OH}$. The eluate was freeze-dried and stored at $-20^{\circ} \mathrm{C}$, prior to $\mathrm{GC}-$ MS analyses.

\section{GC-MS analyses}

Lysine enrichments in the freeze-dried eluates were determined as the $n$-butylheptafluorylbutyryl derivatives at $\mathrm{m} / \mathrm{z} 574$ and 580 on a chiral column that allowed resolution of the $\mathrm{D}$ and $\mathrm{L}$ isomers (Lobley et al. 1996). As discussed previously (Lobley et al. 1996), only the fragment ions corresponding to all the lysine $\mathrm{C}$ either as ${ }^{12} \mathrm{C}$ or ${ }^{13} \mathrm{C}$ were monitored. This was termed relative enrichment earlier, but here is defined more conventionally as mpe. AA concentrations were based on gravimetric procedures and the isotope dilution procedure described previously (Calder et al. 1999), using the $t$-butyldimethylsilyl derivatives.

\section{Calculations}

Whole-body irreversible loss rate (ILR, $\mathrm{mmol} / \mathrm{h}$ ) for lysine was calculated from:

$$
\operatorname{ILR}=\left(0 \cdot 99 / \mathrm{mpe}_{\mathrm{b}(\text { or } p)}-1\right) \times \mathrm{I},
$$

where $b$ and $p$ represent the enrichment (mpe) of free lysine, in either blood or plasma respectively, and I is the rate of $\left[\mathrm{L}-{ }^{13} \mathrm{C}\right]$ lysine infusion $(\mathrm{mmol} / \mathrm{h})$ in the hydrolysate.

The ILR values were converted to equivalent daily protein flux $(\mathrm{PrF}, \mathrm{g} / \mathrm{d})$ by:

$$
\mathrm{PrF}=\mathrm{ILR} \times 24 \times \mathrm{MM}_{\mathrm{lys}} /\left(\text { protein content } \mathrm{lys}_{\mathrm{ys}}\right),
$$

where $\mathrm{MM}_{\mathrm{lys}}$ is the molecular mass of lysine $(146 \mathrm{~g} / \mathrm{mol})$ and protein content $t_{1 y s}$ is the weight of lysine per $100 \mathrm{~g}$ ovine mixed protein deposited during growth: $(55 \mathrm{~g} / \mathrm{kg}$ protein) (from MacRae et al. 1993).

L-lysine concentrations in red blood cells, $[\mathrm{lys}]_{\mathrm{e}}$, from either arterial or venous sources, were calculated from:

$$
\frac{[\text { lys }]_{\mathrm{b}}-\left([\mathrm{lys}]_{\mathrm{p}} \times(1-\mathrm{PCV})\right)}{\text { PCV }} \text {. }
$$

Similarly, the enrichments of L-lysine in the red blood cells from arterial or venous sources were calculated from:

$$
\frac{[\text { lys }]_{\mathrm{b}} \times \mathrm{mpe}_{\mathrm{b}}-\left([\mathrm{lys}]_{\mathrm{p}} \times \mathrm{mpe}_{\mathrm{p}} \times(1-\mathrm{PCV})\right)}{\mathrm{PCV} \times[\mathrm{lys}]_{\mathrm{e}}} .
$$

\section{Hindquarter lysine kinetics}

For lysine, it was assumed that no catabolism occurs across the hindquarters, as for phenylalanine (Harris et al. 1992).
Net retention of lysine, presumed to be exclusively for protein gain (i.e. no oxidation, nor synthesis of lysinederived metabolites, nor expansion or contraction of the intracellular or extracellular free lysine pool occurs), was calculated as:

$$
\begin{aligned}
\text { lysine uptake }(\mu \mathrm{mol} / \mathrm{min})= & \left(\left[\operatorname{lys}_{\mathrm{a}}\right]_{\mathrm{p}(\text { or b })}-\left[\operatorname{lys}_{\mathrm{v}}\right]_{\mathrm{p}(\text { or b })}\right) \\
& \times \mathrm{F}_{\mathrm{p}(\text { or } \mathrm{b})},
\end{aligned}
$$

for each sample, where [lys] represents free lysine concentration $(\mu \mathrm{M})$ for arterial (a) and venous (v) blood or plasma; $\mathrm{F}$ is the flow $(\mathrm{kg} / \mathrm{min})$ in blood or plasma. Several of the earlier assumptions were aided by the adoption of metabolic steady conditions allied to the frequent feeding regimen.

Lysine for protein synthesis was estimated from the net removal of isotope as lysine:

Lysine for protein synthesis $(\mu \mathrm{mol} / \mathrm{min})$

$$
\begin{aligned}
= & \mathrm{F}_{\mathrm{p}(\text { or b) }} \times\left(\left(\left[\operatorname{lys}_{\mathrm{a}}\right]_{\mathrm{p}(\text { or b })} \times \mathrm{mpe}_{\mathrm{a}, \mathrm{p}(\text { or b })}-\left[\operatorname{lys}_{\mathrm{v}}\right]_{\mathrm{p}(\text { or b })}\right.\right. \\
& \left.\times \mathrm{mpe}_{\mathrm{v}, \mathrm{p}(\text { or b })}\right) /\left[\mathrm{lys}_{\mathrm{y}}\right]_{\mathrm{p}(\text { or b })},
\end{aligned}
$$

where y may be whichever free lysine pool relative enrichment (arterial or venous; blood, plasma, red blood cell or tissue homogenate) is selected to best represent that of the true precursor pool for protein synthesis.

Protein breakdown was calculated by difference, i.e.:

$$
\begin{aligned}
& \text { Lysine from protein degradation }(\mu \mathrm{mol} / \mathrm{min}) \\
& =\text { lysine protein synthesis - lysine uptake. }
\end{aligned}
$$

\section{Statistics}

Comparisons were by ANOVA using Genstat 3.2 for Windows (Lawes Educational Trust, Rothamstead, Herts., UK). For main effects, animals were treated as blocks with period $\times$ intake as treatment. In all cases there was no effect of period and this was excluded. Data were also analysed for both linear and quadratic effects. For comparison between fluids (plasma, blood, red blood cell or tissues), animals were again blocked and the effect of period $\times$ intake $\times$ fluid compared. Again, in no case was period significant and was therefore removed from analysis. Comparison of net lysine balance and protein synthesis was by linear regression.

\section{Results}

All sheep recovered well from the surgery and during the study consumed all the ration offered. Plasma flow $(P=0.026$; Table 1$)$ and blood flow $(P=0.034)$ were increased by intake. The significant effect was due to the elevated values at $2.5 \times \mathrm{M}$; the flows at all other intakes were not significantly different from each other. PCV values were unaffected by intake (mean plasma proportion $69 \%$ (SED 0.9)).

There were no significant increases in lysine concentrations in either plasma or red blood cells (for both arterial 
Table 1. Effect of four levels of maintenance energy intake on hindquarter fluid flows, plasma and red blood cell lysine concentrations in sheep $\dagger$

(Mean values for six sheep)

\begin{tabular}{|c|c|c|c|c|c|c|c|c|}
\hline \multirow[b]{3}{*}{ Intake } & & & \multicolumn{6}{|c|}{ Concentration $(\mu \mathrm{M})$} \\
\hline & \multicolumn{2}{|c|}{ Fluid flows ( $\mathrm{g} / \mathrm{min})$} & \multicolumn{3}{|c|}{ Plasma } & \multicolumn{3}{|c|}{ Red blood cell } \\
\hline & Plasma & Blood & Artery & Vein & $P$ & Artery & Vein & $P$ \\
\hline $0.5 \times M$ & 515.5 & 755.1 & $77 \cdot 6$ & $79 \cdot 0$ & NS & $133 \cdot 8$ & $132 \cdot 3$ & NS \\
\hline $1.0 \times \mathrm{M}$ & 582.8 & 772.8 & $91 \cdot 0$ & 87.4 & * & $151 \cdot 1$ & $151 \cdot 0$ & NS \\
\hline $1.5 \times M$ & 606.8 & 876.1 & $97 \cdot 7$ & $91 \cdot 2$ & * & $150 \cdot 6$ & $149 \cdot 1$ & NS \\
\hline $2.5 \times M$ & 836.0 & 1195.4 & $101 \cdot 4$ & 91.7 & * & $152 \cdot 2$ & $149 \cdot 1$ & 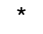 \\
\hline SED & 103.0 & 148.9 & $18 \cdot 4$ & $17 \cdot 6$ & & 11.6 & $11 \cdot 2$ & \\
\hline$P$ (intake) & 0.026 & 0.032 & NS & NS & & NS & NS & \\
\hline
\end{tabular}

M, maintenance energy.

Mean values were significantly different for effects within animal and within fluid but between sample sites (ANOVA): ${ }^{\star} P<0.05$

$\dagger$ For details of diets and procedures, see p. 566.

‡ ANOVA, with animals as blocks and intake as treatment (there was no period effect); 15 residual d.f. There were no significant linear quadratic effects.

and venous samples) with intake (Table 1). At all intakes, the concentration of lysine in the red blood cells was greater $(P<0 \cdot 001)$ than in the plasma by approximately $50 \%$ (from Table 1).

Over the $4 \mathrm{~h}$ of sampling, enrichments of free lysine in both plasma and blood were stable, as were the calculated values for the red blood cells (data not reported). Lysine enrichments measured in plasma were greater than those derived for red blood cells (by 2-3-fold, Table 2). In consequence, distribution of labelled lysine between plasma and red blood cells was 0.71:0.29 (Table 2). This compares with a distribution of unlabelled lysine between the plasma and the red blood cells of approximately $1 \cdot 3: 1$ (from Table 2). Distributions of both labelled and unlabelled lysine were unaffected by intake. As the amount of infused [U- $\left.{ }^{13} \mathrm{C}\right]$ lysine was similar at all intakes, the enrichments of the free amino acid in both arterial and venous plasma were decreased $(P<0.001)$ as intake increased (Table 2). Similar proportional decreases were observed for the red blood cells. At all intakes, lysine enrichment in plasma decreased $(P<0.01$ or lower) across the hindquarters (compare arterial and venous values, Table 2 ). In contrast, the free lysine enrichments in the red blood cells were not different between corresponding arterial and venous samples. Although lysine enrichments in the vascular pools were affected by intake, those in both skin and muscle were not (Table 2), although the variances for the tissue samples were greater. There were no significant differences between lysine enrichments in either arterial or venous red blood cells and those in muscle and skin.

The net uptake of lysine from both plasma and blood by the hindquarters increased with intake (Table 3 ). Net lysine uptake altered in a progressive, linear manner $(P<0 \cdot 001)$ from a catabolic (at $0.5 \times \mathrm{M}$ ) to an anabolic state as intake was increased (Table 3 ). For both plasma and blood the linear equation between intake and hindquarters net lysine balance could account for $75 \%$ of the observed variance $\left(R^{2}\right)$. The net transfers of lysine were similar (and not significantly different) between plasma and blood within each intake (Table 3). In consequence, net movements of lysine via the red blood cells were also not significantly different from zero at any intake (data not shown).

Protein synthesis, calculated based on arterial plasma as the precursor pool, increased linearly with intake $(P<0.001$; Table 3$)$. The same observations $(P<0.001$; linear effects $P<0.001)$ held when either arterial blood (Table 3), venous plasma and venous blood (data not shown) were selected as precursor pools. The absolute values for protein synthesis varied by as much as 2-fold, depending on which was chosen as precursor (Table 3, and data not shown). In addition, the proportional response in protein synthesis with intake varied with the precursor pool selected $(+120 \%,+82 \%,+67 \%$, and $+60 \%$ between 0.5 and $2.5 \times \mathrm{M}$ when arterial plasma, venous plasma, arterial blood and venous blood were chosen respectively). In contrast, the use of enrichments in the intracellular pool of either muscle, skin (or their arithmetic mean, data not

Table 2. Effect of four levels of maintenance energy intake on plasma lysine enrichments across the hindquarters; distribution of total and $\left[{ }^{13} \mathrm{C}\right]$ lysine between plasma and red blood cells, and muscle and skin enrichments in sheep $\dagger$

(Mean values for six sheep)

\begin{tabular}{|c|c|c|c|c|c|c|c|c|c|c|}
\hline \multirow[b]{3}{*}{ Intake } & \multicolumn{6}{|c|}{ Enrichments (mpe) } & \multirow{2}{*}{\multicolumn{2}{|c|}{ Distribution of lysine in plasma (\%) }} & \multirow{2}{*}{\multicolumn{2}{|c|}{ Tissue enrichments (mpe }} \\
\hline & \multicolumn{3}{|c|}{ Plasma } & \multicolumn{3}{|c|}{ Red blood cell } & & & & \\
\hline & Artery & Vein & $\mathrm{P} \S$ & Artery & Vein & $\mathrm{P} \S$ & Total lysine & {$\left[{ }^{13} \mathrm{C}\right]$ lysine $\neq$} & Muscle & Skin \\
\hline $0.5 \times \mathrm{M}$ & $1 \cdot 10$ & 0.84 & $\star \star \star$ & 0.38 & 0.37 & NS & 54.5 & $77 \cdot 1$ & 0.33 & 0.35 \\
\hline $1.0 \times M$ & 0.86 & 0.67 & $\star \star$ & 0.27 & 0.27 & NS & $55 \cdot 3$ & $78 \cdot 8$ & 0.32 & 0.30 \\
\hline $1.5 \times M$ & 0.70 & 0.55 & $\star \star$ & 0.31 & 0.31 & NS & 57.9 & 74.7 & 0.281 & 0.27 \\
\hline $2.5 \times M$ & 0.48 & 0.42 & $\star \star \star$ & 0.21 & 0.21 & NS & $57 \cdot 1$ & 74.8 & 0.29 & 0.24 \\
\hline SED & 0.065 & 0.038 & & 0.03 & 0.04 & & 4.6 & 2.19 & 0.057 & 0.057 \\
\hline$P$ (intake) $\|$ & $<0.001$ & $<0.001$ & & $<0.001$ & $<0.001$ & & NS & NS & NS & NS \\
\hline Linear effects & $\begin{array}{c}<0.001 \\
\text { (quadratic 0.096) }\end{array}$ & $\begin{array}{c}<0.001 \\
\text { (quadratic } 0.026 \text { ) }\end{array}$ & & $<0.001$ & 0.001 & & & & & \\
\hline
\end{tabular}

M, Maintenance energy; mpe, molar percent excess.

$\dagger$ For details of diets and procedures, see p. 566.

$\mp$ Values for red blood cells are (100 - plasma values) and with the same probabilities.

$\S$ Mean values were significantly different (ANOVA, with animals and intake level as blocks; 15 residual d.f.): ${ }^{\star \star} P<0 \cdot 01,{ }^{\star \star \star} P<0 \cdot 001$.

II By ANOVA, with animals as blocks and intake as treatement (there was no period effect); 15 residual d.f. Analyses for significant linear or quadratic effects included.

ๆ One missing value. 
Table 3. Effect of four levels of maintenance energy intake on hindquarter net lysine uptake and estimation of protein synthesis using arterial plasma (or blood), muscle or skin lysine enrichment as precursor pool in six sheep*

(Mean values for six sheep)

\begin{tabular}{|c|c|c|c|c|c|c|}
\hline \multirow{2}{*}{ Intake } & \multicolumn{2}{|c|}{ Lysine uptake ( $\mu \mathrm{mol} / \mathrm{h})$} & \multicolumn{4}{|c|}{ Protein synthesis $(\mu \mathrm{mol} / \mathrm{h})$ in precursor pool } \\
\hline & Plasma & Blood & Arterial plasma & Arterial blood & Muscle & Skin \\
\hline $0.5 \times \mathrm{M}$ & -0.94 & -0.43 & $7 \cdot 7$ & 11.7 & 27.5 & $27 \cdot 6$ \\
\hline $1.0 \times \mathrm{M}$ & 2.42 & 2.45 & $9 \cdot 0$ & $12 \cdot 8$ & $23 \cdot 9$ & 27.5 \\
\hline $1.5 \times M$ & 4.42 & 4.86 & 11.5 & $16 \cdot 5$ & $27 \cdot 9 \ddagger$ & 30.9 \\
\hline $2.5 \times \mathrm{M}$ & $6 \cdot 67$ & $7 \cdot 74$ & $17 \cdot 0$ & $25 \cdot 5$ & 30.4 & $32 \cdot 8$ \\
\hline SED & $1 \cdot 15$ & $1 \cdot 19$ & 1.57 & 2.45 & 4.95 & $6 \cdot 76$ \\
\hline$P+$ & $<0.001$ & $<0.001$ & $<0.001$ & $<0.001$ & NS & NS \\
\hline Linear effects & $<0.001$ & $<0.001$ & $<0.001$ & $<0.001$ & & \\
\hline
\end{tabular}

M, maintenance energy.

* For details of diets and procedures, see p. 566.

† ANOVA, with animals as blocks and intake as treatment (there was no period effect); 15 residual d.f. Analysis for linear and quadratic components included.

$\ddagger$ One missing value.

shown) failed to show significant changes in calculated rates of protein synthesis with intake (Table 3).

There was a linear relationship between protein synthesis, based on vascular enrichments, and net lysine balance across the hindquarters. For net plasma transfers of lysine and protein synthesis calculated based on arterial plasma enrichments the relationship was:

lysine uptake $(\mu \mathrm{mol} / \mathrm{min})$

$$
\begin{aligned}
& =0.62(\text { se } 0.096) \text { protein synthesis }(\mu \mathrm{mol} / \mathrm{min}) \\
& -4.17(\text { se } 1.16)\left(P<0.001, R^{2} 0.64\right),
\end{aligned}
$$

while for venous plasma enrichments:

lysine uptake $(\mu \mathrm{mol} / \mathrm{min})$

$$
\begin{aligned}
& =0.50(\text { se } 0.098) \text { protein synthesis }(\mu \mathrm{mol} / \mathrm{min}) \\
& -4.00(\text { se } 1.42)\left(P<0.001, R^{2} 0.52\right) .
\end{aligned}
$$

The gradients obtained relate to the incremental efficiency with which synthesised protein is retained by the hindquarters.

In contrast to the situation with protein synthesis, intake had no effect on protein breakdown when plasma transfers and enrichments were used (Table 4). For calculations based on blood variables, however, there were trends $(P=0.052$ and 0.075$)$ towards an effect of intake on protein breakdown when arterial and venous values were used respectively (Table 4 and data not shown). The linear trends were also stronger for calculations based on blood $(P=0.014$ and 0.020 respectively), with the values at $2.5 \times \mathrm{M}$ greater than those at other intakes.

Lysine ILR through the plasma, and the corresponding calculated protein flux, increased with intake in a linear manner $(+117 \%$ between $0.5 \times \mathrm{M}$ and $2.5 \times \mathrm{M}, P<0.001$; Table 4). The contribution of the hindquarters (sum of both hindlimbs) to the lysine ILR was approximately $20 \%$, based on arterial plasma data, with this contribution unaffected by intake (Table 4).

\section{Discussion}

\section{Net transfers through blood and plasma}

Studies that have examined the net exchange of AA between the plasma, the red blood cells and tissues have produced conflicting results. For example, with both dogs (Elwyn et al. 1972) and pre-ruminant calves (Houlier et al.

\begin{tabular}{|c|c|c|c|c|c|}
\hline \multirow[b]{2}{*}{ Intake } & \multicolumn{2}{|c|}{ Protein breakdown $(\mu \mathrm{mol} / \mathrm{h}) \dagger$} & \multirow[b]{2}{*}{ Whole-body ILR (mmol/h) } & \multirow[b]{2}{*}{ Whole-body $\operatorname{PrF}(\mathrm{g} / \mathrm{d}) \ddagger$} & \multirow[b]{2}{*}{ Hindquarter PS:ILR (\%) } \\
\hline & Arterial plasma & Arterial blood & & & \\
\hline $0.5 \times \mathrm{M}$ & 8.5 & $12 \cdot 0$ & 2.42 & 153 & $20 \cdot 2$ \\
\hline $1.0 \times \mathrm{M}$ & $7 \cdot 2$ & $11 \cdot 0$ & $2 \cdot 80$ & 187 & $18 \cdot 3$ \\
\hline $1.5 \times \mathrm{M}$ & $8 \cdot 3$ & $12 \cdot 6$ & $3 \cdot 18$ & 223 & $20 \cdot 0$ \\
\hline $2.5 \times \mathrm{M}$ & $9 \cdot 8$ & $17 \cdot 1$ & 4.73 & 306 & $19 \cdot 7$ \\
\hline SED & 1.51 & $2 \cdot 13$ & 0.35 & $27 \cdot 3$ & $3 \cdot 38$ \\
\hline$P$ (intake)§ & NS & 0.052 & $<0.001$ & $<0.001$ & NS \\
\hline Linear effects & & 0.014 & $<0.001$ & $<0.001$ & \\
\hline
\end{tabular}
1991) the general hypothesis has developed that AA

Table 4. Effect of four levels of maintenance energy intake on hindquarter protein breakdown and the hindquarter protein synthesis (based on plasma arterial data):whole-body lysine irreversible loss rate ratio in sheep*

M, maintenance energy; ILR, irreversible loss rate; PrF, protein flux; PS, protein synthesis.

* For details of diets and procedures, see p. 566.

† Calculations based on transfers from either plasma or blood and arterial enrichments (see p. 568).

¥ Calculated as described on p. 570 .

$\S$ ANOVA, with animals as blocks and intake as treatment (there was no period effect); 15 residual d.f. Analysis for linear and quadratic components included. 
(including lysine) are carried from the digestive tract to the liver in plasma, but from the liver to peripheral tissues in the red blood cells. In young sheep, Lobley et al. (1996) concluded that lysine, and the majority of other AA, were transported both to and from the liver via plasma, except for isoleucine and proline. More recently, Le Floc'h et al. (1999) also concluded that splanchnic transfers of lysine in the pig occurred mainly through plasma, with red cell involvement for threonine, valine and alanine. Such evidence would support only a minor role, at best, for the red blood cell transfers in splanchnic tissue metabolism. A similar conclusion for hindquarter transfers of lysine arises from the current results.

Further support for the dominant role of plasma arises from the changes in enrichment across the hindquarters, with only plasma showing a dilution. A similar lack of responsiveness in red blood cell enrichments has been observed across both the digestive tract and liver in sheep (Lobley et al. 1996). These interpretations are confounded, however, by the similarity between the free lysine enrichments of the red blood cell and those within both muscle and skin and thus dynamic exchanges may have occurred, but been undetectable. Nonetheless, any such movements do not appear to involve net transfers.

As previously described for both ruminants and nonruminants (e.g. Keith et al. 1977; Hanigan et al. 1991), lysine concentration in the red blood cell was approximately twice that of plasma, for both arterial and venous samples. How such a concentration gradient is established, and maintained, is unknown, especially as the ovine red blood cell lacks most $\mathrm{Na}^{+}$-dependent AA transporters (Young et al. 1976). Even in rodents, the lysine transport system for red blood cells appears to involve diffusion (Felipe et al. 1990). Another possible explanation for the high concentration of lysine within the red blood cell may involve inward transport and intracellular hydrolysis of oligopeptides (Lochs et al. 1990; Odoom et al. 1990). Although this mechanism has been invoked to explain the similar concentration gradient of histidine (and the lack of transfer of labelled histidine from plasma into the red blood cell), with carnosine ( $\beta$-alanylhistidine) as the substrate (Müller et al. 1980; Lobley et al. 1996), no lysine-containing peptide of suitable concentration has been identified. Transfer from a tissue other than those of the splanchnic region or the hindquarters remains a possibility.

Plasma and red blood cell lysine concentrations in these sheep were much less sensitive to intake than has been observed for human subjects (Aoki et al. 1976), pigs (Keith et al. 1977) and pre-ruminant calves (Houlier et al. 1991). Both Keith et al. (1977) and Le Floc'h et al. (1999) suggested that both the magnitude, and the direction of change, in the partition of the AA between plasma and red blood cells could be modified with intake. Again, the current data do not support these observations, but most of the non-ruminant studies have involved alteration of protein intake rather than changing the amount of mixed ration, as was adopted here. Nutrient balance, therefore, may affect distribution and transfers from vascular fluids. An alternative explanation involves ruminant $v$. non- (or pre-) ruminant differences.

\section{Responses in whole-body and hindquarter lysine metabolism to intake}

Most studies on hindquarter protein metabolism in ruminants have involved use of either a branch-chain AA, usually leucine (e.g. Oddy et al. 1987; Harris et al. 1992), or an aromatic AA, phenylalanine or tyrosine (Boisclair et al. 1993; Crompton \& Lomax, 1993). The branchedchain AA are oxidised across the ruminant hindquarters (e.g. Pell et al. 1986) and may also modify the sensitivity of protein turnover within muscle to insulin (Garlick \& Grant, 1988; Wester et al. 2000). Both oxidation and hormonal sensitisation complicate interpretation of branched-chain AA kinetics. Furthermore, these mechanisms may influence phenylalanine and tyrosine kinetics, because the aromatic AA share a common transporter (the L-system; see Christensen, 1990) with the branched-chain AA. Lysine is transported via a separate $\mathrm{Na}^{+}$-independent system (the $\mathrm{y}^{+}$transporter; see Christensen, 1990) and has not been reported to interact with protein anabolic hormones or growth factors. For these reasons, lysine may prove a suitable alternative as tracer for muscle and hindquarter protein metabolism, where possible complications of nutrient-hormone interactions require to be avoided, or monitored separately.

The linear relationship between intake and net lysine retention across the hindquarters suggests that, even at $2.5 \times \mathrm{M}$ intake, the capacity of the peripheral tissues for net anabolism had not reached maximal values. This was supported by the linear relationship between food intake and whole-body lysine flux. Thus, all the measurements were made over a nutrient-sensitive range, with the increases in ILR of similar magnitude $(+117 \%)$ to those reported for other species (e.g. human subjects, Golden et al. 1977; Ang et al. 1983; pigs, Reeds et al. 1980; steers, Boisclair et al. 1993).

The responses in peripheral tissue protein metabolism to intake reflect the changes in whole-body protein turnover. For example, across a range of species, increased intake has been shown to elevate protein synthesis and deposition in peripheral tissues (e.g. Millward et al. 1976; Seve et al. 1986; Boisclair et al. 1993; Thompson et al. 1997). Most of these studies have involved a small number of intakes and, for the farm species, data above $2 \times \mathrm{M}$ is limited (e.g. Reeds et al. 1980; Harris et al. 1992; Liu et al. 1998). The increased number and range of intakes used within the current study provides a wider database for interpretation. There were, however, no curvilinear responses in peripheral tissue protein synthesis, as proposed by Lobley (1998), although data from the extremes of fasting and intakes $>3 \times \mathrm{M}$, on which that hypothesis was based, were not included in the current study.

When compared with a common precursor pool (arterial plasma enrichments), the contribution of the hindquarters to whole-body protein synthesis remained constant over the wide intake range. This may appear surprising, at first, because muscle tissues are lost at low $\mathrm{N}$ intakes, while other organs such as liver and the digestive tract, are more protected against long-term deprivations (e.g. Cherel et al. 1991). At high $\mathrm{N}$ intakes muscle gain becomes a dominant feature. Therefore, the 
relative contribution of the peripheral tissues to protein turnover might be expected to vary with intake. However, although muscle comprises $60 \%$, or more, of hindquarter mass in sheep (Lobley et al. 1992; Oddy 1993), the metabolic contribution of this tissue is lower due to the higher rate of protein turnover in skin and bone (e.g. Lobley et al. 1980, Lobley et al. 1992; Hunter \& Magner 1990; Rocha et al. 1993). While protein synthesis in muscle, skin and bone alters in response to nutritional changes (Seve et al. 1986; Yahya \& Millward 1994a,b; Liu et al. 1998), there appears to be differential sensitivity for skin and muscle at intakes greater and lesser than M (Liu et al. 1998). Indeed, wool growth continues even under nutritional conditions where there is net mobilisation of muscle protein (Marston, 1948). Thus, maintained metabolic activity in skin (and perhaps bone) may 'compensate' for any reduced contribution from muscle at low intakes.

Responses in ovine peripheral protein degradation to intake can be variable in magnitude (c.f. Harris et al. 1992; Thompson et al. 1997) and may be influenced by age, with protein balance regulated more through breakdown than synthesis in older animals (Teleni et al. 1986). In the current study, only at the $2.5 \times \mathrm{M}$ intake was a significant change in protein degradation observed and the differential sensitivity of protein synthesis and breakdown fits with the known hormonal patterns and actions in response to intake changes (see Lobley, 1998).

These considerations are based on calculations using enrichments of free lysine in vascular pools, and this has been the traditional approach for most arterio-venous procedures. There is evidence, however, that for muscle, the intracellular amino acid may be a more correct precursor (e.g. Lobley et al. 1992; Watt et al. 1992). The enrichment of free lysine in the muscle intracellular pool is lower than that in either plasma or whole blood (but not the red blood cell), as shown by a range of studies (e.g. Lobley et al. 1992; Watt et al. 1992; Biolo et al. 1995a,b). Data on muscle (or skin) intracellular enrichments have been used to extend data from such studies to allow estimates of AA transport in and out of tissues (Biolo et al. 1995a,b). Such biopsies do need to be taken and prepared with special care (Wagenmakers, 1999). Furthermore, single and small biopsy samples may be unrepresentative of hindquarter muscle, particularly as differences in fibre-type composition results in different protein metabolic activity (Garlick et al. 1989). For example, 'white' and 'red' muscles differ in their response to intake (Baillie \& Garlick, 1991) while the high contribution of skin to hindquarter protein metabolism (Hunter \& Magner, 1990; Liu et al. 1998) may emphasise use of AA from the extra-cellular pool (Lobley et al. 1992). In addition, the important contribution of bone cannot be assessed. These various concerns may contribute to the observation that estimated protein synthesis rates across the hindquarters based on muscle intracellular free lysine enrichments failed to show responses to intake, as has been demonstrated in other studies on both ruminants and non-ruminants (e.g. Lobley et al. 1992; Watt et al. 1992; Seve et al. 1993).

The current data strongly indicate that both net and isotope transfers across the ovine hindquarters occur predominantly through plasma with a zero, or minor, contribution from the red blood cell in such exchanges. Over a wide range of intakes, the response in net lysine (protein) balance appears to be regulated by protein synthesis, with protein degradation relatively insensitive to changes in total nutrient supply. The contribution of the hindquarters to whole-body protein synthesis appears to be independent of intake but, within this, the contribution of individual tissues may differ between the various levels of nutrition.

\section{Acknowledgements}

G. Hogan is acknowledged for his statistical advice. The technical expertise of D. Brown, S. E. Anderson, K. Garden, A. G. Calder and D. M. Bremner ensured accurate sample analyses. S. O. H. was the recipient of a postdoctoral fellowship from the Foundation for Research, Science and Technology, New Zealand. This study was funded by SERAD as part of the core budget to the Rowett Research Institute.

\section{References}

Ang SD, Leskiw MJ \& Stein TP (1983) The effect of increasing total parenteral nutrition on protein metabolism. Journal of Parenteral and Enteral Nutrition 7, 525-529.

Aoki TT, Brennan MF, Müller WA, Soeldner JS, Alpert JS, Saltz SB, Kaufmann RL, Tan MH \& Cahill GF (1976) Amino acid levels across normal forearm muscle and splanchnic bed after a protein meal. American Journal of Clinical Nutrition 29, 340-350.

Baillie AG \& Garlick PJ (1991) Responses of protein synthesis in different skeletal muscles to fasting and insulin in rats. American Journal of Physiology 260, E891-E896.

Biolo G, Fleming RYD, Maggi SP \& Wolfe RR (1995a) Transmembrane transport and intracellular kinetics of amino acids in human skeletal muscle. American Journal of Physiology 268, E75-E84.

Biolo G, Fleming RYD \& Wolfe RR (1995b) Physiological hyperinsulinemia stimulates protein synthesis and enhances transport of selected amino-acids in human skeletal-muscle. Journal of Clinical Investigation 95, 811-819.

Boisclair Y, Bauman DE \& Bell AW (1993) Muscle protein synthesis and whole-body $\mathrm{N}$ balance in fed and unfed steers. Journal of Nutrition 123, 1076-1088.

Calder AG, Garden KE, Anderson SE \& Lobley GE (1999) Quantitation of blood and plasma amino acids using isotope dilution mass spectrometry impact gas chromatography/mass spectrometry with $\mathrm{U}_{-}{ }^{13} \mathrm{C}$ amino acids as internal standards. Rapid Communications in Mass Spectrometry 13, 2080-2083.

Cherel Y, Attaix D, Rosolowska-Huszcz D, Belkhov R, Robin J-P, Arnat M \& Le Maho Y (1991) Whole body and tissue protein synthesis during brief and prolonged fasting in the rat. Clinical Science 81, 611-620.

Christensen HN (1990) Role of amino acid transport and countertransport in nutrition and metabolism. Physiological Reviews 70, 43-77.

Crompton LA \& Lomax MA (1993) Hindlimb protein turnover and muscle protein synthesis in lambs: a comparison of techniques. British Journal of Nutrition 69, 345-348.

Elwyn DH, Launder WJ, Parikh HC \& Wise EM (1972) Roles of plasma and erythrocytes in interorgan transport of amino acids in dogs. American Journal of Physiology 222, 1333-1342. 
Felipe A, Vinas O \& Remesar X (1990) Cationic and anionic amino acid transport studies in rat red blood cells. Bioscience of Reproduction 10, 527-535.

Garlick PJ \& Grant I (1988) Amino acid infusion increases the sensitivity of muscle protein synthesis in vivo to insulin. Effect of branched-chain amino acids. Biochemical Journal 254, 579584.

Garlick PJ, Maltin CA, Baillie AG, Delday MI \& Grubb DA (1989) Fiber-type composition of nine rat muscles. II Relationship to protein turnover. American Journal of Physiology 257, E828-E832.

Golden MH, Waterlow JC \& Picou D (1977) Protein turnover, synthesis and breakdown before and after recovery from protein-energy malnutrition. Clinical Science and Molecular Medicine 53, 473-477.

Hanigan MD, Calvert CC, DePeters EJ, Reis BL \& Baldwin RL (1991) Whole blood and plasma amino acid uptakes by lactating bovine mammary glands. Journal of Dairy Science 74, 2484-2490.

Harris PM, Skene PA, Buchan V, Milne E, Calder AG, Anderson SE, Connell A \& Lobley GE (1992) Effect of food intake on hind-limb and whole-body protein metabolism in young growing sheep: chronic studies based on arterio-venous techniques. British Journal of Nutrition 68, 389-407.

Heitmann RN \& Bergman EN (1980) Transport of amino acids in whole blood and plasma of sheep. American Journal of Physiology Endocrinology and Metabolism 239, E242-E247.

Houlier ML, Patureau Mirand P, Durand D, Bauchart D, Lefaivre J \& Bayle G (1991) Transport des acides aminés dans l'aire splanchnique par le plasma sanguin et le sang chez le veau préruminant (Transport of amino acids by plasma and blood across the splanchnic region of pre-ruminant calves). Reproduction Nutrition Development 31, 399-410.

Hunter RA \& Magner T (1990) Whole-body and tissue protein synthesis in steers losing weight on a low-protein roughage diet: the effect of trenbolone acetate. Journal of Agricultural Science 115, 121-127.

Keith MO, Botting HG \& Peace RW (1977) Dietary effects on the concentrations of free amino acids in plasma and whole blood of pigs. Canadian Journal of Animal Science 57, 295-303.

Le Floc'h N, Mézière N \& Sève B (1999) Whole blood and plasma amino acid transfers across the portal drained viscera and liver of the pig. Reproduction, Nutrition Development 39, 433-442.

Liu SM, Mata G, O'Donoghue H \& Masters DG (1998) The influence of live weight, live-weight change and diet on protein synthesis in the skin and skeletal muscle in young merino sheep. British Journal of Nutrition 79, 267-274.

Lobley GE (1998) Nutritional and hormonal control of muscle and peripheral tissue metabolism in farm species. Livestock Production Science 56, 91-114.

Lobley GE, Connell A, Lomax MA, Brown DS, Milne E, Calder AG \& Farningham DAH (1995) Hepatic detoxification of ammonia in the ovine liver, possible consequences for amino acid catabolism. British Journal of Nutrition 73, 667-685.

Lobley GE, Connell A, Revell DK, Bequette BJ, Brown DS \& Calder AG (1996) Splanchnic-bed transfers of amino acids in sheep blood and plasma, as monitored through use of a multiple $\mathrm{U}-{ }^{13} \mathrm{C}$-labelled amino acid mixture. British Journal of Nutrition 75, 217-235.

Lobley GE, Harris PM, Skene PA, Brown D, Milne E, Calder AG, Anderson SE, Garlick PJ, Nevison I \& Connell A (1992) Responses in tissue protein synthesis to sub- and supramaintenance intake in young growing sheep: comparison of large-dose and continuous-infusion techniques. British Journal of Nutrition 68, 373-388.

Lobley GE, Milne V, Lovie JM, Reeds PJ \& Pennie K (1980)
Whole body and tissue protein synthesis in cattle. British Journal of Nutrition 43, 491-502.

Lochs H, Morse EL \& Adibe SA (1990) Uptake and metabolism of dipeptides by human red blood cells. Biochemical Journal 271, 133-137.

MacRae JC, Walker A, Brown D \& Lobley GE (1993) Accretion of total protein and individual amino acids by organs and tissues of growing lambs and the ability of nitrogen balance techniques to quantitate protein retention. Animal Production 57, 237-245.

Marston NR (1948) Nutritional factors involved in wool production by Merino sheep. Australian Journal of Scientific Research 81, 362-375.

Millward DJ, Garlick PJ, Nnanyelugo DO \& Waterlow JC (1976) The relative importance of muscle protein synthesis and breakdown in the regulation of muscle mass. Biochemical Journal 156, 185-188.

Müller M, Dubiel W, Rathmann J \& Rapoport S (1980) Determination and characteristics of energy-dependent proteolysis in rabbit reticulocytes. European Journal of Biochemistry 109, 405-410.

Oddy VH (1993) Regulation of muscle protein metabolism in sheep and lambs: nutritional, endocrine and genetic aspects. Australian Journal of Agricultural Research 44, 901-913.

Oddy VH, Lindsay DB, Barker PJ \& Northrop AJ (1987) Effect of insulin on hind-limb and whole-body leucine and protein metabolism in fed and fasted lambs. British Journal of Nutrition 58, 437-452.

Odoom JE, Campbell ID, Ellory JC \& King GF (1990) Characterization of peptide fluxes into human erythrocytes. Biochemical Journal 267, 141-147.

Pell JM, Caldarone EM \& Bergman EN (1986) Leucine and alpha-ketoisocaproate metabolism and interconversions in fed and fasted sheep. Metabolism: Clinical and Experimental 35, 1005-1016.

Pitts RF, DeHaas J \& Kelin J (1963) Relation of renal amino and amide nitrogen extraction to ammonia production. American Journal of Physiology 204, 187-191.

Reeds PJ, Cadenhead A, Fuller MF, Lobley GE \& McDonald JD (1980) Protein turnover in growing pigs. Effect of age and food intake. British Journal of Nutrition 43, 445-455.

Rocha HJG, Nash JE, Connell A \& Lobley GE (1993) Protein synthesis in ovine muscle and skin: sequential measurements with three different amino acids based on the large-dose procedure. Comparative Biochemistry and Physiology 105B, 301-307.

Savary IC, Hoskin SO \& Lobley GE (1999) Effect of intake on the transfer of lysine to the hindlimb in sheep blood and plasma. In Abstracts of the 8th International Symposium on Protein Metabolism and Nutrition (Aberdeen, UK), p. 18 [GE Lobley, A White and JC MacRae, editors]. Wageningen: Wageningen Pers.

Seve B, Ballevre O, Ganier P, Noblet J, Prugnaud J \& Obled C (1993) Recombinant porcine somatotropin and dietary protein enhance protein synthesis in growing pigs. Journal of Nutrition 123, 529-540.

Seve B, Reeds PJ, Fuller MF, Cadenhead A \& Hay SH (1986) Protein synthesis and retention in some tissues of the young pig as influenced by dietary protein intake after early-weaning. Possible connection to the energy metabolism. Reproduction Nutrition Development 26, 849-861.

Teleni E, Annison EF \& Lindsay DB (1986) Metabolism of valine and the exchange of amino acids across the hind-limb muscles of fed and starved sheep. Australian Journal of Biological Sciences 39, 379-393.

Thompson BC, Hosking BJ, Sainz RD \& Oddy VH (1997) The effect of nutritional status on protein degradation and 
components of the calpain system in skeletal muscle of weaned wether lambs. Journal of Agricultural Science 129, 471-477.

Wagenmakers AJM (1999) Tracers to investigate protein and amino acid metabolism in human subjects. Proceedings of the Nutrition Society 58, 987-1000.

Watt PW, Corbett ME \& Rennie MJ (1992) Stimulation of protein synthesis in pig skeletal muscle by infusion of amino acids during constant insulin availability. American Journal of Physiology 263, E453-E460.

Wester TJ, Lobley GE, Birnie LM \& Lomax MA (2000) Insulin stimulates phenylalanine uptake across the hindlimb in fed lambs. Journal of Nutrition 130, 608-611.
Yahya ZAH \& Millward DJ (1994a) Dietary protein and the regulation of long-bone and muscle growth in the rat. Clinical Science 87, 213-224.

Yahya ZAH, Tirapegui JO, Bates PC \& Millward DJ (1994b) Influence of dietary protein, energy and corticoseroids on protein turnover, proteoglycan sulphuration and growth of long bone and skeletal muscle in the rat. Clinical Science 87, 607618.

Young JD, Ellory JC, Tucker EM \& (1976) Amino acid transport in normal and glutathione-deficient sheep erythrocytes. Biochemical Journal 154, 43-48. 